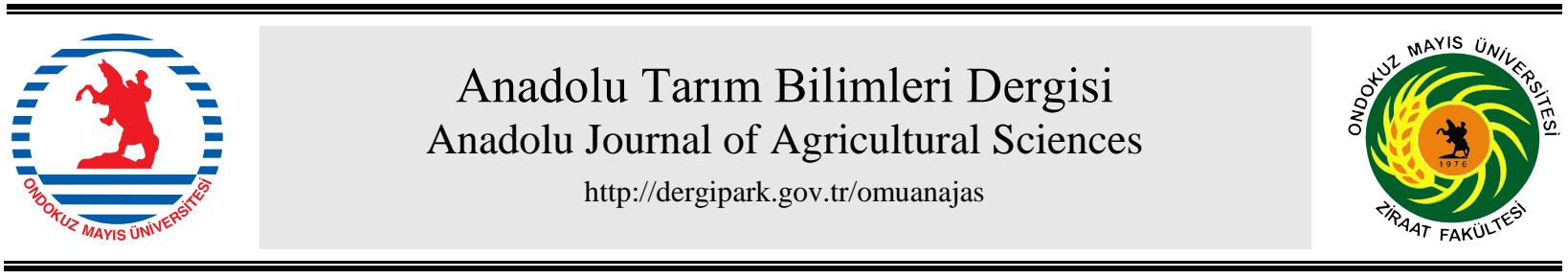

Araştırma/Research

Anadolu Tarım Bilim. Derg./Anadolu J Agr Sci, 34 (2019) ISSN: 1308-8750 (Print) 1308-8769 (Online) doi: $10.7161 /$ omuanajas. 482333

\title{
Yarı kurak iklim koşullarında yazlık olarak yetiştirilen bazı koca fĭğ (Vicia narbonensis L.) çeşitlerinin ot verimi ve kalitesinin belirlenmesi
}

\author{
Nizamettin Turan*, Hamdiye Sakman \\ Siirt Üniversitesi Ziraat Fakültesi, Tarla Bitkileri Bölümü / SİIRT \\ *Sorumlu yazar/corresponding author: nturan49@gmail.com \\ Geliş/Received 13/11/2018 Kabul/Accepted 30/09/2019
}

\begin{abstract}
ÖZET
$\mathrm{Bu}$ araştırma; Siirt Üniversitesi, Ziraat Fakültesi, Araştırma ve Uygulama Arazisi'nde 2016-2017 yıllarında yazlık olarak yetiştirilen bazı koca fiğ (Vicia narbonensis L.) çeşitlerinin ot verimi ve kalitesinin belirlenmesi ve incelenen tarımsal özellikler yönünden adaptasyon kabiliyeti yüksek olan çeşit ya da çeşitlerin belirlenmesi amacıyla yürütülmüştür. Araştırmada; Karakaya, Özgen, Tarman2002 ve Balkan çeşitleri ile Halilbey popülasyonu çalışmanın bitkisel materyalini oluşturmuştur. Deneme tesadüf blokları deneme desenine göre 3 tekerrürlü olarak kurulmuştur. İki yıllık verilere göre çeşitlerin; doğal bitki boylarının 62.8-85.0 cm, kuru ot verimlerinin 272.3-382.0 kg da-1, ham protein oranlarının \% 20.3-21.4, ham protein verimlerinin 55.6-81.3 kg da-1, ADF oranlarının \% 29.3-33.1, NDF oranlarının \% 38.6-44.8 ve nispi yem değerlerinin 149.6-182.8 arasında değişim gösterdiği belirlenmiştir. İncelenen özellikler birlikte değerlendirildiğinde; Siirt ilinin ekolojik koşullarında yazlık olarak yetiştirilen koca fiğ çeşitleri (Vicia narbonensis L.)'nden Balkan çeşidinin verim ve kalite değerleri açısından daha üstün olduğu sonucuna varılmıştır.
\end{abstract}

Determination of herbage yield and quality of some narbon vetch (Vicia narbonensis L.) varieties grown under semi-arid climatic conditions during spring sowing

\section{ABSTRACT}

The aim of this study was to determine the yield and quality of some narbon vetch varieties (Vicia narbonensis L.) grown during spring sowing in Siirt University, Faculty of Agriculture, Research and Application Area in 2016-2017 to determine the varieties with high adaptability in terms of the examined agricultural properties. In the study; Karakaya, Ozgen, Tarman-2002 and Balkan varieties and Halilbey population formed the plant material of the study. The experiment was established as a randomized block design with three replications. Mean of the experimental years, natural plant height, dry herbage yield, crude protein content and yield, ADF and NDF rates and relative feed value (RFV) were ranged between 62.8 and $85.0 \mathrm{~cm}, 272.3$ and $382.0 \mathrm{~kg}$ da-1, 20.3 and $21.4 \%, 55.6$ and $81.3 \mathrm{~kg}$ da$1,29.3$ and $33.1 \%, 38.6$ and $44.8 \%, 149.6$ and 182.8 , respectively. When the features examined are evaluated together, it was concluded that the Balkan variety was superior in terms of yield and quality.

Anahtar Sözcükler: Adaptasyon Besin kalitesi Kuru ot verimi Yazlık ekim Yem bitkisi

\section{Giriş}

Çayır-mera alanları ve yem bitkileri tarımı, hayvansal üretimde kaliteli kaba yemin karşılandığı ana kaynaklar olarak bilinmektedir. Güneydoğu Anadolu Bölgesi hayvancıllı̆ında mera alanları hayvan beslenmesinde çok önemli yer tutmasına karşılık, ülke genelinde olduğu gibi temel sorun olan amaç dışı kullanım ile aşırı ve zamansız otlatma nedeniyle hayvanların ihtiyaç duyduğu kaba yemi karşılamaktan uzaktır. Hayvancılloğ gelişmiş ülkelerde toplam tarla arazisi içerisinde yem bitkilerinin ekiliş oranı \% 20-30 arasında değişirken (Açıkgöz ve ark., 2005; Kuşvuran ve ark., 2011; Aksu ve Dellal, 2016); bu oran Türkiye genelinde \% 9-11 arasında (Kuşvuran ve ark., 2011; Özkan ve Şahin Demirbağ, 2016; TÜİK, 2019) değişmektedir. Bu değer, Güneydoğu Anadolu Bölgesi için \% 1.57(Sayar ve ark., 2010), tarla tarımına ayrılan alanın sınırlı olduğu Siirt ilinde ise yaklaşık \% 7.7 (Turan ve ark., 2015) olduğu rapor edilmiştir. Bu verilere göre ülke genelinde olduğu gibi Siirt ilinde de kaliteli kaba yem açığı bulunmaktadır (Turan ve ark., 2015). Hayvansal üretimin verim ve kalitesini artırmak ve aynı zamanda buna paralel olarak da hayvansal 
üretimin maliyetini düşürmek için tarla tarımı içerisindeki yem bitkisi üretiminin payının arttırılmasına yönelik çalışmalara hı ve önem verilmesi gerekmektedir. Uzun ve ark. (2008)'nın da ifade ettiği üzere, kaliteli kaba yem üretimin artırılması, ülkemizde hayvansal üretimin artırabilmesi noktasında en önemli unsurdur.

Yarı kurak iklim şartlarına sahip Siirt ilinde fiğ türleri içerisinde en fazla macar fiği ve yaygın fiğ yetiştirilmektedir. Genellikle sonbaharda ekilen bu fiğ türlerinin hasadı Mayıs ayında, arpa ve buğday hasatları ise Haziran ayında yapılmaktadır. Hububat hasadından sonra ara ürünlerin rahatlıkla yetişebileceği uzun vejetasyon süresince tarım alanları boş kalmaktadır. $\mathrm{Bu}$ nedenle hububat hasadindan sonra hem kaba yem hem dane ve hem de yeşil gübre materyali olarak kullanım amacıyla ekim nöbetine alınarak koca fiğin yetiştirilmesi, kaba yem açığının azaltılması ve yem bitkisi üretiminde çeşitliliğin sağlanması açısından önem taşımaktadır (El-Bok et al., 2017).

Türkiye'de koca fiğ bitkisi ile yapılan bazı çalışmalarda, örneğin; ICARDA (International Center for Agricultural Research in the Dry Arcas, Suriye)'dan sağlanan farklı orijinli 15 koca fiğ hattı ve yerel hatla Ankara koşullarında yapılan çalışmada; bitki gelişimi, bitki boyu, tane verimi ve hasat indeksi bakımından Lübnan ve Suriye orijinli hatların öne çıktığı, Türkiye orijinli genotiplerin daha çok yeşil ve kuru ot amaciyla yetiştiriciliğine uygun olduğu (Altınok ve ark., 1997) belirlenmiştir. Isparta ekolojik koşullarında çeşide aday 15 koca fiğ hattının bitki boyunun $54.2-64.5 \mathrm{~cm}$ ve biyolojik verimin $559.7-801.8 \quad \mathrm{~kg}^{-1}$ arasinda değiş̧iklik gösterdiği ve ümitvar hatların elde edildiği (Balabanlı, 1998) bildirilmiştir. Bazı ümitvar koca fĭg (V. narbonensis L.) genotiplerinin Güneydoğu Anadolu Bölgesi ekolojik koşullarındaki performanslarının araştırıldığ1 ve kontrol çeşidi olarak Tarman-2002, Karakaya ve Görkem çeşitleri ile Halilbey yerel popülasyonunun kullanıldığ çalışmalarda; bazı koca fiğ hatlarının yeşil ot verimi, kuru madde verimi ve tohum verimi bakımından kontrol çeşitlerine göre daha üstün olduğu ve bu amaçla çeşide aday ümitvar genotiplerin belirlendiği (Sayar ve Han, 2014; Seydoşoğlu ve ark., 2014) rapor edilmiştir.

Siirt ekolojisinde kar örtüsü olmadan meydana gelen soğuk ve don olayları, kışlık erken ve geç ekimleri büyük oranda etkilemekte hatta kesintisiz yağan sonbahar yağmurları ekilen tohumların çürümesine dahi neden olabilmektedir. $\mathrm{Bu}$ nedenle ekimler ilkbahara kalabilmektedir. Ancak bölgede koca fĭğ çeşitlerinin ilkbahar ekimi performanslarıyla ilgili denemeler oldukça kısıtlıdır. Diğer bölgelerde yapılan bazı çalışmalarda koca fiğ çeşitlerinin ülkemizde genellikle kışlık olarak yetiştirilmekle birlikte yazlık ekimlerden de kayda değer verimlerin alınabildiği rapor edilmiştir (Büyükburç ve ark., 1994; İptaş, 1997).

$\mathrm{Bu}$ araştırmada; Siirt ekolojik koşullarında yazlık olarak ekilen bazı koca fiğ (Vicia narbonensis L.) çeşitlerinin ot verimi ve kalitesinin belirlenerek, incelenen tarımsal özellikler yönünden adaptasyon kabiliyeti yüksek olan çeşit ya da çeşitlerin ortaya konulması amaçlanmıştır.

\section{Materyal ve Yöntem}

Araştırma; Siirt Üniversitesi, Ziraat Fakültesi, Araştırma ve Uygulama Arazisi'nde 2016-2017 yıllarında yürütülmüş̧ür. Dicle Üniversitesi Ziraat Fakültesi'nden Karakaya ve Özgen, Tarla Bitkileri Merkez Araştırma Enstitüsü Müdürlüğü'nden Tarman2002, Geçit Kuşağı Tarımsal Araştırma Enstitüsü Müdürlüğ̈̈'nden Balkan çeşitleri ve Mardin'den sağlanan Halilbey popülasyonunun bitkisel materyal olarak kullanıldığı araştırmada; tarla denemeleri tesadüf blokları deneme desenine göre üç tekerrürlü olarak kurulmuştur. Sıra arası mesafenin $25 \mathrm{~cm}$, her parseldeki sıra sayısının 8, parsel alanının $4 \mathrm{~m} \mathrm{x} 2 \mathrm{~m}=8 \mathrm{~m}^{2}$ 'dir.

Ekim işlemi her iki yılda da Mart ayının ilk haftasında yapılmış olup, dekara $18 \mathrm{~kg}$ hesabıyla tohumluk kullanılmıştır (TTSM, 2001). Bitkilerin çıkış ve gelişme dönemlerinde görülen yabancı otlar ile mücadele elle çapa yapmak suretiyle yapılmıştır. Bitkilerin alttan birkaç baklanın oluştuğu dönemde ve parsel kenarlarından birer sıra, parsel başlarından ise 0.5 m'lik kısımlar kenar tesiri olarak atıldıktan sonra, hasat işlemi gerçekleştirilmiştir. Araştırmanın her iki yılında da hasat işlemi Haziran ayının ilk haftasında yapılmıştır. Her parselden biçilen yeşil otlar tartılmış ve parsel alanı dikkate alınarak dekara yeşil ot verimleri hesaplanmıştır. Elde edilen yeşil ot içerisinden rastgele 500 g'lık örnekler alınarak kurutma dolabında 48 saat süreyle $70{ }^{\circ} \mathrm{C}$ 'de kurutulmuş (Uzun, 2010) ve belirlenen kuru ot oranları, parsellerin yeşil ot verimleri ile çarpılarak dekara kuru ot verimleri hesaplanmıştır. Kurutulan örnekler her parsel için ayrı ayrı ögütülmüş ve analizler için hazır hale getirilmiştir. Örneklerin ham protein (HP) ile asit ve nötral deterjanda çözünmeyen lif (ADF ve NDF) oranları; Ondokuz Mayıs Üniversitesi, Ziraat Fakültesi, Tarla Bitkileri Bölümü Laboratuvarı'nda, NIRS (Near Infrared Reflektance Spectroscopy-Yakın Kızll Ötesi Yansımas1 Spektroskopisi) cihaz1 ile \#IC-0904FE kalibrasyon seti (WCS, 2018) kullanılarak belirlenmiştir (Brogna et al., 2009). Çalışmada ot kalitelerinin belirlemesine yönelik olarak HP oranı ile ilgili değerler, kuru ot verimleri ile çarpılması sonucu dekara HP verimleri belirlenmiştir.

ADF ve NDF oranlarından sindirilebilir kuru madde (SKM \%) [SKM=88.9-(0.779 x \% ADF)], kuru madde tüketimi $($ KMT \%) $(\mathrm{KMT}=120 / \% \mathrm{NDF})$ ve nispi yem değeri (NYD \%) [NYD= (SKM x KMT)/1.29] formüller yardımıyla hesaplanmıştır (Van Dyke and Anderson, 2000).

Her parselden rastgele seçilen 10 adet bitkide doğal bitki boyu ölçümleri TTSM (2001)'e göre yapılmıştır. Araştırma sonucunda elde edilen veriler; JUMP istatistik paket programı yardımıyla tesadüf blokları deneme desenine göre varyans analizine tabi tutulmuş, ortalamalar arasindaki farkl111klar LSD testi ile karşılaştırılmıştır (Yurtsever, 1984). 


\subsection{Araştırma alanının iklim özellikleri}

Tipik karasal iklimin hâkim olduğu Siirt ilinin uzun yıllar ortalama yağış miktarı $713.10 \mathrm{~mm}$, nispi nem oranı \% 44.73, sıcaklık ise $16.08{ }^{\circ} \mathrm{C}$ olarak ölçülmüştür. Araştırmanın yapıldığı yıllarda nispi nemin en yüksek olduğu Ocak ayında sirasıyla \% 76.04 ve $\% 66.11$ olarak gerçekleşirken, sıcaklık (sırasıyla $1.69{ }^{\circ} \mathrm{C}$ ve 2.95 ${ }^{\circ} \mathrm{C}$ ) genel olarak düşük olmuştur (Çizelge 1).

Denemenin yürütüldüğü yılların sıcaklık ve nispi nem ortalamaları, uzun yıllar sıcaklık ve nispi nem ortalamalarının üzerinde gerçekleşmiştir. Araştırmanın ilk yılında gerçekleşen toplam yağış miktarı (731.20 $\mathrm{mm})$ uzun yilların ortalamasından $(713.10 \mathrm{~mm})$ daha yüksek, ikinci yıl (540.80 mm) ise daha düşük olmuştur. Siirt ilinin yaz ayları sıcak ve kurak geçtiğinden dolayı deneme parselleri hasada kadar ilk yıl 2, ikinci yıl ise 4 defa sulamaya ihtiyaç duymuştur (Çizelge 1).

\subsection{Araştırma yerinin toprak özellikleri}

Tarla denemeleri kurulmadan önce alınan toprak örneklerinin analiz sonuçlarına göre; killi-kumlu bünyeli, nötr karakterli ve tuzluluk problemi bulunmayan, orta ve fazla kireçli arasında değiştiği, organik madde kapsamının az, alınabilir fosfor içeriğinin çok az ve alınabilir potasyum miktarının ise yeterli düzeyde olduğu belirlenmiştir (Çizelge 2).

Çizelge 1. Araştırma yerinin uzun yıllar (1960-2017) ve araştırma yılları bazı iklim verileri (MBM, 2017)

\begin{tabular}{|c|c|c|c|c|c|c|c|c|c|}
\hline \multirow{2}{*}{ Aylar } & \multicolumn{3}{|c|}{ Ortalama sıcaklık $\left({ }^{\circ} \mathrm{C}\right)$} & \multicolumn{3}{|c|}{ Toplam yağış (mm) } & \multicolumn{3}{|c|}{ Nispi nem (\%) } \\
\hline & UYO & 2016 & 2017 & UYO & 2016 & 2017 & UYO & 2016 & 2017 \\
\hline Ocak & 2.60 & 1.69 & 2.95 & 96.80 & 162.40 & 48.80 & 73.30 & 76.04 & 66.11 \\
\hline Şubat & 4.20 & 8.06 & 2.74 & 97.50 & 63.80 & 26.60 & 68.50 & 68.39 & 64.49 \\
\hline Mart & 8.30 & 10.07 & 9.54 & 111.10 & 135.60 & 126.60 & 60.4 & 62.35 & 64.16 \\
\hline Nisan & 13.70 & 16.70 & 14.00 & 104.70 & 66.80 & 124.60 & 50.40 & 47.45 & 59.18 \\
\hline May1s & 19.30 & 19.90 & 19.55 & 62.00 & 64.60 & 74.60 & 41.50 & 48.92 & 51.62 \\
\hline Haziran & 26.00 & 26.52 & 26.94 & 8.70 & 20.40 & 0.0 & 24.10 & 32.63 & 29.44 \\
\hline Temmuz & 30.60 & 31.37 & 32.28 & 1.60 & 2.40 & 0.0 & 18.10 & 24.48 & 18.99 \\
\hline Ağustos & 30.10 & 32.28 & 31.94 & 0.90 & 0.20 & 0.40 & 17.20 & 20.55 & 18.99 \\
\hline Eylül & 25.10 & 24.86 & 28.31 & 4.90 & 18.80 & 0.0 & 24.00 & 29.82 & 19.22 \\
\hline Ekim & 17.90 & 19.49 & 18.35 & 49.10 & 40.20 & 18.40 & 45.30 & 37.10 & 35.15 \\
\hline Kasım & 10.40 & 10.33 & 11.13 & 81.40 & 51.80 & 73.40 & 57.10 & 49.82 & 64.44 \\
\hline Aralık & 4.80 & 3.35 & 7.95 & 94.40 & 104.2 & 47.40 & 56.9 & 72.92 & 65.29 \\
\hline Toplam/Ortalama & 16.08 & 17.05 & 17.14 & 713.10 & 731.20 & 540.80 & 44.73 & 47.54 & 46.42 \\
\hline
\end{tabular}

UYO: Uzun y1llar ortalamas1

Çizelge 2. Araştırma yeri topraklarının bazı fiziksel ve kimyasal özellikleri $(0-20 \mathrm{~cm})^{*}$

\begin{tabular}{|c|c|c|}
\hline \multirow[b]{2}{*}{ Toprak özelliği } & \multicolumn{2}{|c|}{ Değerler } \\
\hline & 2016 & 2017 \\
\hline Kil, \% & 51.32 & 44.10 \\
\hline Kum, \% & 41.64 & 36.12 \\
\hline Silt, \% & 22.3 & 19.78 \\
\hline $\mathrm{pH}$ & 6.87 & 7.21 \\
\hline Elektriksel iletkenlik, dS m${ }^{-1}$ & 0.602 & 0.147 \\
\hline Kireç, \% & 6.4 & 16.30 \\
\hline Organik madde, $\%$ & 0.90 & 1.96 \\
\hline Alınabilir fosfor, $\mathrm{kg}_{2} \mathrm{O}_{5} \mathrm{da}^{-1}$ & 1.7 & 2.40 \\
\hline Alınabilir potasyum, $\mathrm{kg} \mathrm{K}_{2} \mathrm{O} \mathrm{da}^{-1}$ & 114 & 620.00 \\
\hline
\end{tabular}

*: Analizler; Siirt Üniversitesi, Bilim ve Teknoloji Uygulama ve Araştırma Merkezi Laboratuvarı'nda yapılmıştır
Belirlenen toprak analiz sonuçlarına göre her ekim yılında $2.7 \mathrm{~kg} \mathrm{da}^{-1}$ saf azot ve $6.9 \mathrm{~kg} \mathrm{da}^{-1}$ saf fosfor $\left(\mathrm{P}_{2} \mathrm{O}_{5}\right)$ olacak şekilde azotlu ve fosforlu gübreleme (Diamonyum fosfat, \% 18-46-0) yapılmıştır.

\section{Bulgular ve Tartışma}

\subsection{Doğal bitki boyu}

İncelenen koca fiğ çeşitlerinin doğal bitki boyu değerleri Çizelge 3'te verilmiştir. İki yıllık ortalama verilerle yapılan varyans analiz sonuçlarına göre; çeşitler ve yıllar arasında önemli farklılıklar belirlenmiştir. En yüksek bitki boyu $85.0 \mathrm{~cm}$ ile Balkan çeşidinde saptanmış olup, bu çeşit ile Özgen $(78.7 \mathrm{~cm})$ çeşidi aynı istatistiki grupta yer almıştır. Çalışmada, en kısa bitki boyu $62.8 \mathrm{~cm}$ ile Halilbey popülasyonunda saptanmıştır. Çeşitlerin yıllara göre ortalaması ise sırasıyla $67.9 \mathrm{~cm}$ ve $78.9 \mathrm{~cm}$ olarak gerçekleşmiştir (Çizelge 3). 
Çizelge 3. Koca fiğ çeşitlerinde belirlenen doğal bitki boyu, yeşil ve kuru ot verimlerine ilişkin değerler ${ }^{1}$

\begin{tabular}{|c|c|c|c|c|c|c|c|c|c|}
\hline \multirow{2}{*}{ Genotipler } & \multicolumn{3}{|c|}{ Doğal bitki boyu $(\mathrm{cm})$} & \multicolumn{3}{|c|}{ Yeşil ot verimi $\left(\mathrm{kg} \mathrm{da}^{-1}\right)$} & \multicolumn{3}{|c|}{ Kuru ot verimi $\left(\mathrm{kg} \mathrm{da}^{-1}\right)$} \\
\hline & 2016 & 2017 & Ortalama & 2016 & 2017 & Ortalama & 2016 & 2017 & Ortalama \\
\hline Balkan & 82.3 & 87.7 & $85.0^{\mathrm{a}}$ & 1347.3 & 1493.3 & $1420.3^{\mathrm{a}}$ & $377.0^{\mathrm{ab}}$ & $387.0^{\mathrm{a}}$ & $382.0^{\mathrm{a}}$ \\
\hline Tarman-2002 & 65.3 & 76.0 & $70.7^{b}$ & 1146.0 & 1349.3 & $1247.7^{\mathrm{b}}$ & $296.3^{\mathrm{cd}}$ & $333.3^{\mathrm{b}}$ & $314.8^{b c}$ \\
\hline Halilbey & 52.3 & 73.3 & $62.8^{c}$ & 820.3 & 1113.3 & $966.8^{d}$ & $260.3^{\mathrm{e}}$ & $284.3^{c-e}$ & $272.3^{d}$ \\
\hline Özgen & 75.6 & 81.7 & $78.7^{\mathrm{ab}}$ & 1220.3 & 1370.0 & $1295.2^{b}$ & $271.7^{\mathrm{de}}$ & $388.3^{\mathrm{a}}$ & $330.0^{\mathrm{b}}$ \\
\hline Karakaya & 64.0 & 75.7 & $69.8^{\mathrm{b}}$ & 1023.6 & 1156.7 & $1090.2^{c}$ & $312.4^{\mathrm{bc}}$ & $275.0^{\text {de }}$ & $293.7^{\mathrm{cd}}$ \\
\hline Ortalama & $67.9^{\mathrm{B}}$ & $78.9^{\mathrm{A}}$ & & $1111.5^{\mathrm{B}}$ & $1296.5^{\mathrm{A}}$ & & 303.5 & 333.60 & \\
\hline
\end{tabular}

LSD değerleri

\begin{tabular}{lccc} 
Çeşit & 5.6 & 69.6 & ÖD \\
Y1l & 6.3 & 66.6 & 23.8 \\
Çeşit x y1l & ÖD & ÖD & 33.7 \\
\hline
\end{tabular}

${ }^{1}$ Aynı sütunda ve satırda farklı harfle gösterilen ortalamalar arasında fark vardır $(\mathrm{p}<0.01)$.

Araştırmada koca fiğ çeşitlerinin doğal bitki boyu ile ilgili elde edilen değerler; İptaş ve Karadağ (2009) tarafından Tokat-Kazova ekolojik koşullarında yazlık olarak yetiştirilen koca fiğ hatlarından elde ettikleri ortalama bitki boyu (sırasıyla 66.3-67.7 cm) değerlerinden daha yüksek olduğu belirlenmiştir. Bilakis Budak (1996), kışlık ekimlerin yazlık ekimlere göre daha fazla boylanma sağladığını vurgulamasına rağmen bulgularımız; Balabanlı (1998)'nın Isparta ekolojik koşullarında $(54.2-64.5 \mathrm{~cm})$, Nizam ve ark. (2011)'nın Tekirdağ, Kırklareli ve Hayrabolu lokasyonlarında (43.0-78.9 cm), Sayar ve Han (2014) ile Seydoşoğlu ve ark. (2014)'nın Diyarbakır koşullarında (sırasıyla 63.8-79.3 cm, 44.2-61.3 cm) kışlık olarak yetiştirdikleri koca fiğ çeşit ve hatlarının doğal bitki boyu ile ilgili elde ettikleri bulguların bazılarından yüksek, bazıları ile benzerlik gösterdiği saptanmıştır. Siirt ilinde yapılan yazlık koca fiğ ekimlerinde ülkemizin birçok bölgesindeki kışlık ekimler kadar boy değerleri elde edildiği anlaşılmaktadır. Ankara koşullarında 15 koca fiğ hattı ve 1 adet yerel hatla kışlık ekimlerle yapılan bir başka çalışmada; bitki boyu bakımından yıllar arasında önemli farkl1lıkların belirlendiği, incelenen hatların her iki yılda da farklı performanslar sergilediği ve yıl $\mathrm{x}$ hat interaksiyonunun da istatistiksel açıdan çok önemli çıktığı rapor edilmiştir (Altınok ve ark., 1997). Nitekim Stoilova and Pereira (1999), bitki boyu kalıtsal bir özellik ise de çevresel faktörler bu karakter üzerinde etkili olduğunu ifade etmektedirler.

Bazı araştırıcılar (Büyükburç ve İptaş, 2001; Sayar ve Han, 2014) tarafindan da ifade edildiği üzere doğal bitki boyu açısından yıllar arasında ortaya çıkan farklılığın iklim koşullarından kaynaklandığı düşünülmektedir. Çizelge 1'de iklim verileri incelendiğinde; araştırmanın ilk yılına göre ikinci yılda daha az yağışın düştüğü görülmektedir. Bundan dolayı da ikinci yılda daha fazla yapilan sulamalar bitki boyunda etkili olduğu değerlendirilmektedir.

\subsection{Yeşil ot verimi}

Yeşil ot verimi yönünden yıllar ve çeşitler arasında $\mathrm{p}<0.01$ düzeyinde çok önemli farklılıklar belirlenmiştir. Bu farklılıklar, çeşitlerin ekolojik koşullara gösterdikleri reaksiyondan kaynaklandığı düşünülmektedir. Özellikle, araştırmanın ilk yılında düşen toplam yağış miktarının ikinci yıla göre daha yüksek olması, çeşitlerin iklim ve çevre şartlarına göre performanslarının farklı olmasına neden olduğu söylenebilir. Bazı araştırıcılar da (Açıkgöz ve ark., 1986; Karadağ ve Büyükburç, 2004; Sayar ve Han, 2014) tek y1llık baklagil yem bitkilerinin verimi büyük ölçüde ilkbahar mevsiminde düşen yağmurlara bağlı olduğunu ifade etmektedirler.

Çalışmanın ilk yılına (2016) göre, ikinci yılda (2017) daha yüksek yeşil ot veriminin elde edilmiş olması da, bitkilerin büyüme döneminde daha fazla yapılan sulamaların olumlu etkilerinden kaynaklandığı değerlendirilmektedir. Koca fĭg çeşitleri arasında Balkan çeşidinden en yüksek yeşil ot verimi $(1420.3 \mathrm{~kg}$ $\mathrm{da}^{-1}$ ) elde edilirken, en düşük yeşil ot verimi Halilbey popülasyonunda $\left(966.8 \mathrm{~kg} \mathrm{da}{ }^{-1}\right)$ tespit edilmiştir. Çeşitlerin 2016 ve 2017 yıllarına ait ortalama yeşil ot verimleri ise surasiyla $1111.50 \mathrm{~kg} \mathrm{da}^{-1}$ ve $1296.50 \mathrm{~kg} \mathrm{da}^{-}$ ${ }^{1}$ olarak gerçekleşmiştir (Çizelge 3 ).

Koca fiğ çeşitlerine ait yeşil ot verimleri; İptaş ve Karadağ (2009)'ın Tokat koşullarında yazlık olarak yetiştirdikleri koca fiğ hatlarından elde ettikleri ortalama yeşil ot verimlerinden $(5058-4186 \mathrm{~kg} / \mathrm{da})$ daha düşük iken; Çaçan ve Kökten (2017)'in Bingöl şartlarında en uygun ekim zamanını belirlemek amacıyla yazlık olarak yetiştirdikleri çeşitlerden elde ettikleri ortalama yeşil ot verimlerinden (463.10-628.60), Balabanlı (1998)'nın Isparta koşullarında kışlık ekimlerden elde ettiği ortalama yeşil ot verimlerinden (559.7-801.8 $\left.\mathrm{kg} \mathrm{da}^{-1}\right) \mathrm{ve}$ Özyiğit (2018)'in Antalya sahil koşullarında koca fiğ (Vicia narbonensis L.) için uygun ekim normunu belirlemek amacıyla kışlık olarak yürüttüğü araştırmada elde ettiği en yüksek biyolojik verimden $\left(1026 \mathrm{~kg} \mathrm{da}^{-1}\right)$ daha yüksek olduğu saptanmıştır.

Ayrica elde edilen bulgular; Nizam ve ark. (2011)'nın farklı lokasyonlarda $1549.9-1912.7 \mathrm{~kg} \mathrm{da}^{-1}$, Sayar ve Han (2014)'ın Diyarbakır koşullarında 2378- 
$3126 \mathrm{~kg} \mathrm{da}{ }^{-1}$, Seydoşoğlu ve ark. (2014)'nın yine Diyarbakır ekolojik koşullarında 2207.0-4097.8 kg da ${ }^{-1}$ arasında değişen miktarlarda kışlık ekimlerden elde ettikleri yeşil ot verimlerinden daha düşük olduğu tespit edilmiştir.

Yeşil ot verimi ile ilgili elde edilen değerler ile literatürlerde rapor edilen bu değerler arasındaki farklılığın sebebi olarak, yetiştirilen toprak ve iklim gibi ekolojik koşulların farklılığı, ekim zamanı ve genotipik özelliklerden kaynaklanmış olabilir. Bitkilerin kök gelişimi her ne kadar genetik özelliklere bağlı ise de kışlık ekimlerde daha iyi geliştiği söylenebilir. Çünkü kışlık ekimlerde vejetasyon dönemi uzamakta ve uzun vejetasyon döneminde bitki köklerde daha fazla yedek besin maddesi birikmektedir. Ayrıca sonbahar ekimlerde daha fazla derine inen kökler bitki besin maddelerinden, kış ve ilkbahar yağışlarından daha fazla faydalanabilmektedir. $\mathrm{Bu}$ gibi durumlar, bitkilerin ilkbahar gelişmesini hızlandırmakta ve daha fazla yeşil aksam meydana getirmesine neden olduğu düşünülmektedir.

\subsection{Kuru ot verimi}

Kuru ot veriminin ortalama sonuçları incelendiğinde; en yüksek kuru ot verimi $382.00 \mathrm{~kg} \mathrm{da}^{-1}$ ile Balkan çeşidinden belirlenirken, en düşük kuru ot verimi $272.30 \mathrm{~kg} \mathrm{da}^{-1}$ ile Halilbey popülasyonundan elde edilmiştir. İlk yıla göre ikinci yılda bir miktar daha fazla kuru ot elde edilmesine rağmen, kuru ot verimi bakımından yıllar ortalaması (sırasıyla $303.50 \mathrm{~kg} \mathrm{da}^{-1}$, $333.60 \mathrm{~kg} \mathrm{da}^{-1}$ ) arasında önemli bir fark görülmemiştir (Çizelge 3). Bu durum, araştırmanın ilk yılında düşen yağış miktarının yüksek, sıcaklıkların düşük; ikinci yılında ise sıcaklıkların yüksek ve yağış miktarının daha düşük olması yeşil otun içerdiği kuru madde oranının artmasına neden olduğu tahmin edilmektedir (Çizelge $1)$.

Yine çalışmanın ilk yılında kuru ot verimi $(377 \mathrm{~kg}$ $\mathrm{da}^{-1}$ ) yönünden Balkan çeşidi öne çıkarken, ikinci yılında aralarındaki farklılık istatistiki açıdan önemsiz olan Özgen (388.30 kg da $\left.{ }^{-1}\right)$ ve Balkan $\left(387 \mathrm{~kg} \mathrm{da}^{-1}\right)$ çeşitlerinden en yüksek verim elde edilmiștir. Bunun sonucu olarak; çeşit $\mathrm{x}$ yıl interaksiyonunun çok önemli $(\mathrm{p}<0.01) \quad$ çımasına neden olmuştur. Çeşit $\mathrm{x}$ yıl interaksiyonunun önemli çıkması ise çeşitlerin yıllara göre farklı performans gösterdiğini ortaya koymaktadır (Çizelge 3).

Kuru ot verimi ile ilgili elde edilen bulgular; Çaçan ve Kökten (2017) Bingöl ekolojik koşullarında yazlık ekim zaman1 ve genotiplerin ortalaması olarak 28.1$184.7 \mathrm{~kg} \mathrm{da}^{-1}$, Nizam ve ark. (2011) Tekirdağ, Kırklareli ve Hayrabolu lokasyonlarının ortalamas1 olarak 255.3-332.6 kg da ${ }^{-1}$ arasında elde ettikleri kuru ot verimlerinden yüksek olduğu; Sayar ve Han (2014) 489$633 \mathrm{~kg} \mathrm{da}^{-1}$, Seydoşoğlu ve ark. (2014) $526.2-935.2 \mathrm{~kg}$ $\mathrm{da}^{-1}$ arasında değişen miktarlarda kışlık ekimlerden elde ettikleri kuru ot verimlerinden ise daha düşük olduğu belirlenmiştir.
Kışlık olarak ekilen bitkilerin büyüme dönemi daha uzun olduğundan, hem kış hem de ilkbahar yağışlarını değerlendirmesi nedeniyle yazlık ekilen ürünlerden daha verimli olduğu (Akyürek, 1974; Budak, 1996) araştırıcılar tarafından ifade edilse de, farklı ekolojik koşullara bağlı olarak araştırmamızda elde edilen kuru ot verimlerinin, bazı kışlık ekimlerden elde edilen kuru ot verimlerinden daha yüksek olduğu saptanmıştır. Nitekim bazı araştırıcılar (Robinson, 1960; Roberts et al., 1989; Tahtacıoğlu ve ark., 1996), kışlık ekimlerde fiğlerin kış soğuklarından zarar gördüğünü ve çimlenen fidelerin bir kısmının hayatiyetlerini kaybettiklerini ifade etmektedirler. Dolayısıyla kış zararının olduğu ekolojilerde yazlık ekimlerin daha verimli olabilecekleri söylenilebilir.

\subsection{Ham protein (HP) oranı}

Yılların ortalaması olarak çeşitlerin ham protein oranları \% 20.3 ile \% 21.4 arasında değişmiş ve aralarında istatistiki farklılık görülmemiştir. Çeşitlerin ilk y1 HP oranı ortalamas1 (\% 19.9), ikinci yıl

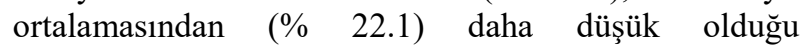
saptanmıştır (Çizelge 4). Bazı araştırıcılar (Ayan ve ark., 2006; Kaplan, 2013; Yücel ve ark., 2014), HP oranının yıllara göre farklılık göstermesinin ekolojik koşullardan ve genotipik farklılıklardan kaynaklanabileceği, Ball et al. (2001) ise çeşitler arasındaki HP oranlarının farklılığında bitkinin genetik yapısının da rol oynadığını ifade etmektedirler. Bununla birlikte çeşitler arasındaki farklılıklar bitkilerin sahip oldukları yaprak/sap oranı ve gelişme durumları ile de alakalı olabilir. Nitekim Caballero et al. (1995), fiğde ham protein oranlarının yapraklarda (\% 16.8) saplara göre daha fazla olduğunu belirtmişlerdir.

Koca fiğ ile ilgili farklı ekolojilerde yürütülen çalışmalarda HP oranlarının \% 13.60-22.46 arasında değiştiği bildirilmiştir (Özer, 1992; Altınok ve Hakyemez, 2002; Başbağ ve ark., 2011; Rahmati et al., 2012; Sungur, 2016). Karakaya ve Özgen çeşitlerinin bitkisel materyal olarak kullanıldığı bir çalışmada (Çaçan ve Kökten, 2017), ekim zamanlarına göre ham protein oranlarının \% 18.7 ile \% 27.3 arasında değiştiği rapor edilmiştir. Ayrıca Budak ve ark. (1997), fiğ türlerinin ham protein oranlarının \% 18.34-22.70 arasında değiştiğini bildirmektedirler. Araştırmada elde edilen bulgular, literatürlerde rapor edilen değerler aralığında olduğu söylenebilir.

\subsection{Ham protein verimi}

Çeşitler arasında en yüksek ortalama HP oranı Balkan $\left(81.3 \mathrm{~kg} \mathrm{da}^{-1}\right)$ çeşidinde, en düşük ise Halilbey $\left(55.6 \mathrm{~kg} \mathrm{da}^{-1}\right)$ popülasyonunda belirlenmiştir.

Çeşitlerin ilk yıl ham protein verimi ortalaması 60.7 $\mathrm{kg} \mathrm{da}{ }^{-1}$ iken, ikinci yıl $73.6 \quad \mathrm{~kg} \mathrm{da}^{-1}$ olarak gerçekleşmiştir. Araştırmanın ilk yılında bazı çeşitlerin (Tarman-2002, 
Çizelge 4. Koca fiğ çeşitlerinde belirlenen HP oranı ve HP verimlerine ilişkin değerler ${ }^{1,2}$

\begin{tabular}{|c|c|c|c|c|c|c|}
\hline \multirow{2}{*}{ Genotipler } & \multicolumn{3}{|c|}{ Ham protein oranı $(\%)$} & \multicolumn{3}{|c|}{ Ham protein verimi $\left(\mathrm{kg} \mathrm{da}^{-1}\right)$} \\
\hline & 2016 & 2017 & Ortalama & 2016 & 2017 & Ortalama \\
\hline Balkan & 20.1 & 22.4 & 21.3 & $76.0^{b c}$ & $86.6^{a}$ & $81.3^{\mathrm{a}}$ \\
\hline Tarman-2002 & 20.9 & 21.8 & 21.4 & $61.7^{\mathrm{d}}$ & $72.8^{c}$ & $67.2^{b c}$ \\
\hline Halilbey & 19.2 & 21.5 & 20.3 & $50.2^{\mathrm{e}}$ & $61.0^{\mathrm{d}}$ & $55.6^{\mathrm{d}}$ \\
\hline Özgen & 20.4 & 21.9 & 21.2 & $55.2^{\mathrm{de}}$ & $85.3^{a b}$ & $70.3^{b}$ \\
\hline Karakaya & 19.2 & 22.6 & 20.9 & $60.2^{\mathrm{d}}$ & $62.2^{\mathrm{d}}$ & $61.2^{\mathrm{cd}}$ \\
\hline Ortalama & $19.9^{\mathrm{B}}$ & $22.1^{\mathrm{A}}$ & & $60.7^{\mathrm{B}}$ & $73.6^{\mathrm{A}}$ & \\
\hline \multicolumn{7}{|l|}{ LSD değerleri } \\
\hline Çeşit & & & ÖD & & & 6.7 \\
\hline Yil & & & 16 & & & 8.9 \\
\hline Çeşit x y1l & & & ÖD & & & 9.4 \\
\hline
\end{tabular}

${ }^{1}$ Aynı sütunda ve satırda farklı harfle gösterilen ortalamalar arasında fark vardır $(\mathrm{p}<0.01)$.

${ }^{2}$ Aynı sütunda ve satırda farklı harfle gösterilen ortalamalar arasında fark vardır $(\mathrm{p}<0.05)$.

Özgen) HP verimi istatistiki olarak düşük grupta yer alırken, aynı çeşitler ikinci yılda daha yüksek grupta yer almıştır. Bu durum; çeşit $\mathrm{x}$ yıl interaksiyonunun çok önemli ( $\mathrm{p}<0.01)$ çıkmasına neden olmuştur (Çizelge 4).

Araştırmada koca fiğ çeşitlerinden elde edilen ham protein verimi; koca fiğ çeşitleriyle farklı ekolojilerde yazlık olarak yürütülen çalışmalarda elde edilen $45.9 \mathrm{~kg}$ $\mathrm{da}^{-1}$ (Sungur, 2016) ve $35.00 \mathrm{~kg} \mathrm{da}^{-1}$ (Çaçan ve Kökten, 2017) ham protein verimlerinden daha yüksek bulunurken; Ankara koşullarında kışlık olarak ekilen koca fiğ bitkisinden elde edilen $81 \mathrm{~kg} \mathrm{da}^{-1}$ (Altınok ve Hakyemez, 2002) ham protein verimi ile uyumlu olduğu saptanmıştır.

HP verimi bakımından görülen bu farklılıklar; kullanılan çeşitlerin farklı oluşu, yetiştirildikleri toprakların kimyasal özellikleri ve bitki besin madde içeriklerinin farklı olmasından kaynaklandığı düşünülmektedir.

\subsection{ADF ve NDF oranı}

Çeşitlerin ADF ve NDF oranı bakımından yıllar arasındaki farklılık ile yıl x çeşit interaksiyonu istatistiki olarak önemsiz iken, NDF oranları açısından çeşit ortalamaları arasındaki farklılık $\mathrm{p}<0.05$ düzeyinde önemli olduğu belirlenmiştir. Çeşitlerin ortalamaları arasındaki bu farklılık bitkilerin sahip oldukları yaprak/sap oranı, toprak ve iklim özellikleri, gelişme durumları ve genetik yapıları ile alakalı olabilir. Nitekim Karslı ve ark., (2005) tarafindan yapılan bir çalışmada NDF, ADF ve ADL içeriklerinde meydana gelen değişimlerin bitkisel materyallerdeki genotipik farklılıklardan ileri geldiği ifade edilmektedir.

Toplam sindirilebilir besin maddelerinin bir göstergesi olan ADF bakımından çeşitler arasında farklılık görülmemiş ve değerleri $\% 29.3$ ile 33.1 arasında değişmiştir.

Bitkilerdeki hücre duvarı bileşenlerinden (selüloz+lignin+hemiselüloz) oluşan NDF oranları ise çeşitlere göre \% 38.6-44.8 arasında varyasyon göstermiş, en düşük NDF oranı \% 38.6 ile Özgen, en yüksek ise \% 44.8 ile Karakaya çeşidinde saptanmıştır (Çizelge 5). Bilindiği üzere kaba yemlerde NDF oranının düşük olması istenen bir özelliktir. Yani; yemin sindirim derecesinin yüksek olması, o yemin hücre duvarı bileşenlerinin düşük olmasına da bağlıdır (Van Soest, 1994; Kaya, 2008; Kutlu, 2008; Gürsoy ve Macit, 2014).

Koca fiğ bitkisinde; ADF \% 24.1-35.4, NDF \% 28.2-46.0 arasında değişen oranlarda bulunduğu (Türk ve ark., 2007; Öztürk, 2009; Başbağ ve ark., 2011; Rahmati et al., 2012; Sungur, 2016; Çaçan ve Kökten, 2017; Kaplan ve ark., 2017; Uslu ve ark., 2018) ifade edilmektedir. Araştırmada ADF ve NDF oranı ile ilgili elde edilen bulgular, önceki çalışma bulgularıyla uyumlu olduğu belirlenmiştir.

Koca fiğ çeşitlerinin ADF ve NDF oranları değerlendirildiğinde; baklagil, buğdaygil ve baklagil karışımlarına ait kalite standartlarına (Rohweder et al., 1978) göre en üstün kaliteli ve çok iyi kaliteli sınıfında yem elde edildiği görülmektedir. $\mathrm{Bu} \mathrm{da;} \mathrm{koca} \mathrm{fiğ}$ çeşitlerinden elde edilen kuru otun sindirilme derecesinin yüksek olduğunu göstermektedir.

\subsection{Nispi yem değeri (NYD)}

Çeşitlerin ilk yıl NYD ortalaması 150.7 iken, ikinci yıl 178.2 olarak gerçekleşmiştir (Çizelge 5). İki yılın ortalamasına göre en yüksek NYD değerleri Özgen (182.8) ve Balkan (174.0), en düşük ise Karakaya (149.6) çeşidi ve Halilbey (152.9) popülasyonunda belirlenmiştir. Özgen çeşidi Rohweder et al. (1978)'nn sinıflandırmasına göre en üstün kalite sınıfında yer alırken, Karakaya çeşidi ise 1. kalite (çok iyi) sınıfında yer almaktadır.

Farklı ekolojilerde yapılan çalışmalarda, koca fiğ çeşit ve hatlarının nispi yem değerlerinin 125.7-164.0 arasında değiştiği (Öztürk, 2009; Kaplan ve ark., 2017) ifade edilmektedir. Güneydoğu Anadolu Bölgesi doğal meralarından toplanan $V$. narbonensis türlerinde 147.6 ve 158.2 (Başbağ ve ark., 2011), Sinop ili Saraydüzü ilçesi ekolojik koşullarında yetiştirilen koca fiğin yazlık 
ekimlerinde ise 133.0 (Sungur, 2016) olarak nispi yem değerlerinin belirlendiği rapor edilmiştir. Gerek denemede yer alan çeşitler ve bu çeşitlerin yillara göre gösterdikleri performanslar ile gerekse diğer çalışma değerleri arasında belirlenen farklılıklar; çeşitlerin genotipik özellikleri ile çalışma yerlerinin ve yıllarının ekolojik koşullarından kaynaklandığı ifade edilebilir.

Çizelge 5. Koca fiğ çeşitlerinde belirlenen ADF ve NDF oranları ile otun nispi yem değeri (NYD) ${ }^{1,2}$

\begin{tabular}{lccccccccc}
\hline \multirow{2}{*}{ Genotipler } & \multicolumn{3}{c}{ ADF (\%) } & \multicolumn{3}{c}{ NDF (\%) } & \multicolumn{3}{c}{ NYD } \\
\cline { 2 - 10 } & 2016 & 2017 & Ortalama & 2016 & 2017 & Ortalama & 2016 & 2017 & Ortalama \\
\hline Balkan & 30.5 & 32.5 & 31.5 & 39.9 & 43.9 & $41.9^{\mathrm{b}}$ & 152.2 & 195.7 & $174.0^{\mathrm{ab}}$ \\
Tarman-2002 & 30.4 & 33.7 & 32.1 & 41.9 & 46.5 & $44.2^{\mathrm{ab}}$ & 146.4 & 179.8 & $163.2^{\mathrm{bc}}$ \\
Halilbey & 30.2 & 30.3 & 30.2 & 41.7 & 43.0 & $42.4^{\mathrm{ab}}$ & 146.5 & 159.3 & $152.9^{\mathrm{c}}$ \\
Özgen & 28.4 & 30.1 & 29.3 & 37.4 & 39.8 & $38.6^{\mathrm{c}}$ & 166.5 & 199.1 & $182.8^{\mathrm{a}}$ \\
Karakaya & 31.0 & 35.1 & 33.1 & 42.8 & 46.7 & $44.8^{\mathrm{a}}$ & 141.9 & 157.2 & $149.6^{\mathrm{c}}$ \\
\hline Ortalama & 30.1 & 32.4 & & 40.7 & 44.0 & & $150.7^{\mathrm{B}}$ & $178.2^{\mathrm{A}}$ & \\
\hline LSD değerleri & & & & & & & & & \\
Çeşit & & & ÖD & & & 2.6 & & & 2.7 \\
Y1l & & & ÖD & & & ÖD & & & 11.9 \\
Çeşit x y1l & & ÖD & & & ÖD & & & ÖD \\
\hline
\end{tabular}

${ }^{1}$ Aynı sütunda ve satırda farklı harfle gösterilen ortalamalar arasında fark vardır $(\mathrm{p}<0.01)$.

${ }^{2}$ Aynı sütunda ve satırda farklı harfle gösterilen ortalamalar arasında fark vardır $(\mathrm{p}<0.05)$.

\section{Sonuç}

Siirt ekolojik koşullarında yazlık olarak ekilen bazı koca fiğ çeşitlerinin (Vicia narbonensis L.) adaptasyon kabiliyetlerinin belirlenmesi amacıyla yürütülen bu çalışmada, koca fiğ çeşitlerinin yazlık olarak yetiştirilebileceği ve tatmin edici verim ve kalite değerlerinin elde edilebileceği anlaşılmıştır. Diğer yandan denemede yer alan çeşitler içerisinde de Balkan çeşidinin çalışma alanı ve benzer ekolojiler için doğru tercih olacağı sonucuna varılmıştır.

\section{Teșekkür}

Bu çalışmanın ilk yıl sonuçları; Siirt Üniversitesi, Bilimsel Araştırma Projeleri Koordinatörlüğü tarafından "2016-SİÜFEB-12" No'lu proje ile desteklenmiştir.

\section{Kaynaklar}

Açıkgöz, E., Turgut, I., Ekiz, H., 1986. Variation of seed yield and its compenents in common vetch under different conditions. XVI. International Grassland Congress, Nice-France, 641-642.

Açıkgöz, E., Hatipoğlu, R.., Altınok, S., Sancak, C., Tan, A., Uraz, D., 2005. Yem bitkileri üretimi ve sorunları. Türkiye Ziraat Mühendisliği VI. Teknik Tarım Kongresi, 503-518, 3-7 Ocak, Ankara.

Aksu, N., Dellal, İ., 2016. Afyonkarahisar ilinde yem bitkileri desteğinin büyükbaş hayvancılık faaliyetleri ile ilişkisinin değerlendirmesi. Yüzüncü Yıl Üniversitesi Tarım Bilimleri Dergisi, 26(1): 52-60. doi.org/10.29133/yyutbd.236430.

Akyürek, A., 1974. Erzurum Ovas1 ve Doğu Anadolu'nun diğer yerlerinde arpa yetiştirme imkanları ve bu hususta bölümümüzde bugüne kadar yapılan araştırmalar. 1. Hayvancılık, Çayır-Mera ve Yembitkileri Teknik Kongresi. T.M.M.O.B. Ziraat Mühendisleri Odas1, 54: 109-117.

Altınok, S., Sevimay, C.S., Hakyemez, B.H., 1997. Ankara koşullarında koca fiğ (Vicia narbonensis L.) hatlarında adaptasyon çalışmaları. Tarla Bitkileri Merkez Araştırma Enstitüsü Dergisi, 6(2): 23-29.

Altınok, S., Hakyemez, H., 2002. The effects on forage yields of different mixture rates of hairy vetch (Vicia villosa L.) and narbonne vetch (Vicia narbonensis L.) seeded with barley (Hordeum vulgare L.). Journal of Agricultural Sciences, 8(1): 45-50.

Ayan, İ., Acar, Z., Başaran, U., Önal Aş̧̧ı, Ö., Mut, H., 2006. Samsun ekolojik koşullarında bazı burçak (Vicia ervilia L.) hatlarının ot ve tohum verimlerinin belirlenmesi. Ondokuz Mayis Üniversitesi Ziraat Fakültesi Dergisi, 21(3): 318-322.

Balabanl, C., 1998. Isparta ekolojik şartlarında bazı koca fiğ hatlarının (Vicia narbonensis L.) verim ve adaptasyonu. Tarla Bitkileri Merkez Araştırma Enstitüsü Dergisi, 7(2): 51-56.

Ball, D.M., Collins, M., Lacefield, G.D., Martin, N.P., Mertens, D.A., Olson, K.E., Putnam, D.H., Undersander, D.J., Wolf, M.W., 2001. Understanding forage quality. American Farm Bureau Federation Publication 1-01, Park Ridge, IL. Available

at:http://forages.oregonstate.edu/resources/publicatio ns/foragequality. pdf (Access date: 15 November 2013).

Başbağ, M., Çaçan, E., Aydın, A., Sayar, M.S., 2011. Güneydoğu Anadolu Bölgesi doğal alanlarından toplanan bazı fĭg türlerinin ot kalite ve özelliklerinin belirlenmesi. Uluslararası Katılımlı I. Ali Numan Kıraç Tarım Kongresi ve Fuarı, 143-151, 27-30 Nisan, Eskişehir. 
Brogna, N., Pacchioli, M.T., Immovilli, A., Ruozzi, F., Ward, R., Formigoni, A., 2009. The use of nearinfrared reflectance spectroscopy (NIRS) in the prediction of chemical composition and in vitro neutral detergent fiber (NDF) digestibility of Italian alfalfa hay. Ital. J. Anim. Sci., 8(Suppl. 2): 271-273.

Budak, F., 1996. Kayseri ekolojik şartlarında farklı ekim zamanlarının bazı fiğ (Vicia sp.) türlerinin tarımsal özelliklerine etkisi üzerine bir araştırma (Yüksek Lisans Tezi). Gaziosmanpaşa Üniv. Fen Bil. Enst. Tarla Bit. Anabilim Dalı, Tokat.

Budak, F., Büyükburç, U., Budak, H., 1997. Kayseri ekolojik koşullarında farklı ekim zamanlarının bazı fiğ (Vicia sp.) türlerinin tarımsal özelliklerine etkisi üzerine bir araştırma. Türkiye II. Tarla Bitkileri Kongresi, 22-27 Eylül 1997, s: 696-698, Samsun.

Büyükburç, U., İptaş, S., Yılmaz, M., 1994. A research on determination of annual some forage the legumes which will be adaptabtable in Tokat region. Gaziosmanpasa University Journal of Agriculture Faculty, 11: 145-156.

Büyükburç, U., İptaş, S., 2001. The yield and yield components of some narbonne vetch (Vicia narbonensis L.) lines in Tokat ecological conditions. Turkish Journal of Agriculture and Forestry, 25(2): 79-88.

Caballero, R., Haj Ayed, M., Galvez, J.F., Herna1z, P.J., 1995. Yield components and chemical composition of some annual legumes under continental mediterranean conditions. Int $\mathrm{J}$ Agric Sci Agricolture Mediterranea, 125, 220-230.

Çaçan, E., Kökten, K., 2017. Bingöl koşullarında yaygın fiğ ve koca fiğ çeşitleri için uygun ekim zamanının belirlenmesi. Türk Doğa ve Fen Dergisi, 6(1): 19-23.

El-Bok, S., Jabri, C., Ben-Brahim, T., Lamine, O., ElGazzah, M., Zoghlami-Khélil, A., 2017. Pod, seed traits and cytotaxonomic studies of some Vicia narbonensis L. accessions (Fabaceae). Saudi Journal of Biological Sciences, 24(7): 1689-1696. doi.org/10.1016/j.sjbs.2015.11.003.

Gürsoy, E., Macit, M., 2014. Erzurum ili meralarında doğal olarak yetişen bazı buğdaygil yem bitkilerinin in vitro gaz üretim değerlerinin belirlenmesi. Yüzüncü Yıl Üniversitesi, Tarım Bilimleri Dergisi, 24(3): 218-227.

İptaş, S., 1997. Yazlık olarak yetiştirilen bazı koca fĭg (Vicia narbonensis L.) hatlarında tohum verimi ve bazı agronomik özellikler arasındaki ilişkiler. Gaziosmanpaşa Üniversitesi, Ziraat Fakültesi Dergisi, 1: 146-154.

İptaş, S., Karadağ, Y., 2009. Determination of the yield and yield components of narbon vetch (Vicia narbonensis L.) lines grown in spring. 1st International Symposium on Sustainable Development, 83-88, June 9-10, Sarajevo.

Kaplan, M., 2013. Yaygın fĭ̆ (Vicia sativa L.) genotiplerinde hasat zamanının ot verimi ve kalitesine etkisi. Erciyes Üniversitesi, Fen Bilimleri Enstitüsü Dergisi, 29(1): 76-80.
Kaplan, M., Kökten, K., Kale, H., Kardeş, Y.M., Akcura, M., Satana, A., 2017. Herbage yield and quality of different narbon vetch lines and cultivars. 2nd International Balkan Agriculture Congress, 120126, 16-18 May, Tekirdağ-Turkey.

Karadağ, Y., Büyükburç, U., 2004. Effect of different seed ratios on forage and seed yield of some common vetch cultivars under Tokat-Kazova conditions. Journal of Agricultural Sciences, 10(2): 149-157.

Karslı, M.A., Akdeniz, H., Levendoğlu, T., Terzioğlu, Ö., 2005. Evaluation of the nutrient content and protein fractions of four different common vetch varieties. Turk J. Vet. Anim. Sci. 29:pp.1291-1297.

Kaya, Ş., 2008. Kaba yemlerin değerlendirilmesinde göreceli yem değeri ve göreceli kaba yem kalite indeksi. Türk Bilimsel Derlemeler Dergisi, 1(1): 5964.

Kuşvuran, A., Nazlı, R.İ., Tansı, V., 2011. Türkiye'de ve Batı Karadeniz Bölgesi'nde çayır-mera alanları, hayvan varlığı ve yem bitkileri tarımının bugünkü durumu. GOÜ, Ziraat Fakültesi Dergisi, 28(2): 2132.

Kutlu, H.R., 2008. Yem değerlendirme ve analiz yöntemleri. Ders Notu, Çukurova Üniversitesi, Ziraat Fakültesi, Zootekni Bölümü, Adana, http://www.zootekni.org.tr/upload/File/sunular/tm.p df (Erişim tarihi: 02 Ocak 2019).

MBM, 2017. Meteoroloji Bölge Müdürlüğü Kayıtları, Siirt ili iklim verileri.

Moneim, A.M.A.E., 1992. Narbon vetch (Vicia narbonensis L.) A potential feed legume crop for dry areas in West asia. Journal of Agronomy and Crop Science 169, 347-353.

Nizam, I., Orak, A., Kamburoglu, I., Cubuk, M.G., Moralar, E., 2011. Yield potentials of narbonne vetch (Vicia narbonensis L.) genotypes in different environmental conditions. Journal of Food Agriculture \& Environment, 9(1): 314-318. doi.org/10.1234/4.2011.1958.

Özer, İ., 1992. Konya ili anız alanlarında doğrudan ekim sureti ile baklagil yembitkileri yetiştirme imkânları üzerine bir araştırma. Yüksek Lisans Tezi (Basılmamış), Selçuk Üniversitesi, Fen Bilimleri Enstitüsü, Konya.

Özkan, U., Şahin Demirbağ, N., 2016. Türkiye'de kaliteli kaba yem kaynaklarını mevcut durumu. Türk Bilimsel Derlemeler Dergisi, 9(1): 23-27.

Öztürk, M., 2009. Bazı kışlık yem bitkilerinde çinkolu gübrelemenin verim ve kalite üzerine etkileri. Yüksek Lisans Tezi, Adnan Menderes Üniversitesi, Fen Bilimleri Enstitüsü, Aydın, 73s.

Özyiğit, Y., 2018. Antalya sahil koşullarında koca fiğ (Vicia narbonensis L.) yetiştiriciliği için uygun ekim normunun belirlenmesi. Türkiye Tarımsal Araştırmalar Dergisi, 5(1): 72-78. doi.org/10.19159/tutad.363186.

Rahmati, T., Azarfar, A., Mahdavi, A., Khademi, K., Fatahnia, F., Shaikhahmadi, H., Darabighane, B., 
2012. Chemical composition and forage yield of three Vicia varieties (Vicia spp.) at full blooming stage. Italian Journal of Animal Science, 11(e57): 309-311. doi:10.4081/ijas.2012.e57.

Roberts, C.A., Moore, K.J., Johnson, K.D., 1989. Forage quality and yield of wheat and vetch at different stages of maturity and vetch seeding rates. Agron. J., 81(1):57-60.

Robinson, R. C., 1960. Oat-pea or oat-vetch mixtures for forage or seed. Agron. J., 52 (8), 546-549.

Rohweder, D.A., Barnes, R.F., Jorgensen, N., 1978. Proposed hay grading standards based on laboratory analyses for evaluating quality. Journal of Animal Science, 47(3): 747-759.

Sayar, M.S., Anlarsal, A.E., Başbağ, M., 2010. Güneydoğu Anadolu Bölgesi'nde yem bitkileri tarımının mevcut durumu sorunları ve çözüm önerileri. Harran Üniversitesi Ziraat Fakültesi Dergisi, 14(2): 59-67.

Sayar, M.S., Han, Y., 2014. Determination of forage yield performance of some promising narbon vetch (Vicia narbonensis L.) lines under rainfed conditions in Southeastern Turkey. Journal of Agricultural Sciences, 20: 376-386.

Seydoşoğlu, S., Sayar, M.S., Başbağ, M., 2014. Diyarbakır ekolojik koşullarında bazı koca fĭg genotiplerinin verim ve verim unsurları. Türk Tarım ve Doğa Bilimleri Dergisi, 1(1): 64-71.

Sungur, M.B., 2016. Sinop Saraydüzü ilçesinde bazı tek yıllık baklagil yem bitkilerinin verim ve kalite özelliklerinin belirlenmesi. Yüksek Lisans Tezi, Süleyman Demirel Üniversitesi, Fen Bilimleri Enstitüsü, Isparta, 42s.

Stoilova, T., Pereira, M.G., 1999. Morphological characterization of 120 lentil (Lens culinaris Medic.) accessions. Lens Newsletter, (1999), 1-2, pp. 7-9

Tahtacioğlu, L., Avcı, M., Mermer, A., Şeker, H., Aygün, C., 1996. Bazı kışlık fiğ çeşitlerinin Erzurum ekolojik koşullarına adaptasyonu. Türkiye 3. ÇayırMer'a ve Yembitkileri Kongresi, 17-19 Haziran 1996, Erzurum, 661-667.

TTSM, 2001. Tarımsal değerleri ölçme denemeleri teknik talimat, fĭg türleri (Vicia L. species). T.C. Tarım ve Köyişleri Bakanlı̆̆ı, Tohumluk Tescil ve Sertifikasyon Merkezi Müdürlüğü, http://www.tarim.gov.tr/BUGEM/TTSM/Belgeler/T escil/Teknik\%20Talimatlar/Yem\%20Bitkileri/Bakla
gi1\%20Yem\%20Bitkileri/01fig.pdf (Erişim tarihi: 18 Haziran 2018).

Turan, N., Özyazıcı, M.A., Yalçın Tantekin, G., 2015. Siirt ilinde çayır mera alanlarından ve yem bitkilerinden elde edilen kaba yem üretim potansiyeli. Türkiye Tarımsal Araştırmalar Dergisi, 2(1): 69-75. doi.org/10.19159/tutad.37366.

TÜİK, 2019. Bitkisel üretim istatistikleri. Türkiye İstatistik Kurumu, http://tuik.gov.tr/PreTablo.do?alt_id=1001 (Erişim tarihi: 07 Ocak 2019).

Türk, M., Albayrak, S., Yüksel, O., 2007. Effects of phosphorus fertilisation and harvesting stages on forage yield and quality of narbon vetch. New Zealand Journal of Agricultural Research, 50(4): 457-462. doi.org/10.1080/00288230709510313.

Uslu, Ö.S., Kurt, Ö., Kaya, E., Kamalak, A., 2018. Effect of species on chemical composition, metabolizable energy, organic matter digestibility and methane production of some legume plants grown in Turkey. Journal of Applied Animal Research, 46(1): 1158-1161. doi.org/10.1080/09712119.2018.1480485.

Uzun, F., Sulak, M., Uğur, S., 2008. Gazal boynuzu türlerinin ülkemiz için önemi. Türk Bilimsel Derlemeler Dergisi, 1(2): 45-54.

Uzun, F., 2010. Kuru madde analizi (IV. Analizler) Uzun F. (Ed.), Tarla Bitkilerinde Laboratuvar Analizleri (Uygulama Ders Notu), OMÜ, Ziraat Fak., Ders Notu No:1, 25-27, Samsun.

Van Dyke, N.J., Anderson, P.M., 2000. Interpreting a forage analysis. Alabama Cooperative Extension, Circular ANR-890.

Van Soest, P.J., 1994. Nutritional ecology of the ruminant (2nd Ed.). Ithaca, N.Y. Cornell University Press. p. 528.

Yurtsever, N., 1984. Deneysel istatistik metodlar1. Tarım ve Köy Hizmetleri Genel Müdürlügü Yayınları No: 121, Ankara.

Yücel, C., Yücel, D., Akkaya, M.R., Anlarsal, A.E., 2014. Bazı ümitvar yaygın fiğ (Vicia sativa L.) genotiplerinde kalite özellikleri. Kahramanmaraş Sütçü İmam Üniversitesi, Doğa Bilimleri Dergisi, 17(1): 8-14.

WCS, 2018. Win ISI 4 Calibration Software: Ground, expandable equation packages. http://www.winisi.com/product_calibrations.htm (Erişim tarihi: 20 Kasım 2018). 